\title{
INTERPRETING FRANCHISORS' PREFERENCES IN THE TRAVEL AGENCY INDUSTRY: THE CASE OF SPAIN
}

\author{
J. M. RAMIREZ-HURTADO, * F. M. GUERRERO-CASAS, * AND F. J. RONDAN-CATALUÑ $\dagger$ \\ *Department of Economy, Quantitative Methods and Economic History, \\ Pablo de Olavide University, Seville, Spain \\ $\dagger$ Department of Marketing, University of Seville, Seville, Spain
}

\begin{abstract}
Travel agency industry is one of the most important and relevant activities of franchise in many countries. One key aspect necessary for the suitable development of the franchise system in any country is the expansion of the franchisors. For this challenge to be a success, the franchisors must select the franchisees correctly. In this work the characteristics of potential franchisees preferred by franchisors are analyzed. A study was made in one of the most dynamic and important industries of the franchise system, that of travel agencies, and it used a combination of the methodologies of conjoint analysis and principal component analysis. The results show the profile preferred by the franchisors and give a ranking of the most important characteristics that the franchisors look for in travel agency franchisees.
\end{abstract}

Key words: Franchising; Preferences; Travel agency; Conjoint analysis; Principal component analysis

Introduction

The importance of tourism in the economy of countries has long been recognized and studied in the previous years and literature. It is generally agreed that the tourism market makes a significant contribution to the economic development of a large number of countries (Kandampully, 1995, 2000; World Tourism Organization [WTO], 1998). This field has experienced rapid changes in research focus and methodological sophistication (Xiao \& Smith, 2006).
The travel agency industry is closely related to tourism. Travel agencies have an increasing role in specific areas of the traditional travel agent business, such as travel consultancy and troubleshooting (Dolnicar \& Laesser, 2007). In the same sense, travel agency industry is one of the most important and relevant activities of franchising in many countries.

Franchising has experienced considerable growth in countries throughout the world. This is evidenced by the numerous franchising fairs that are held every year; the publication of specialized books and

Address correspondence to J. M. Ramirez-Hurtado, Department of Economy, Quantitative Methods, and Economic History, Pablo de Olavide University . Ctra. De Utrera, km. 1, s/n 41013 Seville, Spain. Tel.:+34 954349171; fax: +34 954349339;

E-mail: jmramhur@upo.es 
magazines; the publication of scientific works in this sphere; the huge number of consultants advising on this commercial system; the configuration of Internet portals on franchising, as well as the publicity carried out by the franchisor brands (Ramirez, 2007).

The travel agency industry includes a significant part of the franchising system in many countries. Thus, in Spain, according to data from Mundofranquicia Consulting (2008), in 2007 there were 39 brands in the travel agency industry, which represented $3.4 \%$ of the total number of brands, occupying ninth position by brand ranking and experiencing a growth of $34.5 \%$ with respect to the previous year. Regarding the number of franchised establishments, in 2007 there were 5,684 establishments in the travel agency industry in Spain, which represented $8.2 \%$ of the total franchised establishments, which experienced a growth of $16.0 \%$ with respect to the previous year. With these data, the average brand size of the travel agency industry is 145.7. The average turnover of each brand of the travel agency industry is $36,543,867$ Euros, one of the highest among all sectors. In addition, the average number of employees per establishment in the travel agency industry is 3.19 workers. This means travel agency industry is fragmented and generates a significant level of employment. All these figures show that the travel agency industry is one of the most important and dynamic within the franchising system in Spain.

However, in spite of the important role travel agencies play within tourism and their difficult situation to face the future, there is a lack of research on travel agencies (Moreno \& Aguiar, 2006).

One key aspect necessary for the suitable development of the franchise system in any country is the expansion of the franchisors. For this challenge to be successful the franchisors must select the franchisees correctly. This correct selection must not be based solely on experience, intuition, or chance, but must be aided by robust studies. A poor franchisee selection will lead to the failure at the point of sale, with the corresponding damages and deterioration of the brand image of the franchisor as a consequence.

This study tries to contribute to the improvement of the franchisee selection process, focusing on the travel agency industry. It does this by identifying the franchisee profile preferred by the franchisors that operate in the travel agency industry. The franchisee profile has to bring together a series of personal and entrepreneurial characteristics that, to a great extent, will mark the success or failure of the activity of the franchisee and, consequently, the success or failure of the chain (Ramirez, 2007). Among these characteristics the following can be emphasized: entrepreneurial capacity, professional experience motivation, financial situation, personality, extroversion, communication ability, desire for success, etc. (Cho, 2004; Clarkin \& Swavely, 2006; Edens, Self, \& Grider, 1976; Forward \& Fulop, 1993; Jambulingam \& Nevin, 1999; Kahn, 1994; Tatham, Douglas, \& Bush, 1972; Tormo \& Associates, 2004). Although establishing a generic franchisee profile is difficult due to the diversity of franchising chains, it is possible to obtain common basic criteria for all franchise systems.

The methodologies used in this work are conjoint analysis and principle component analysis. In order to improve the interpretation of the results of conjoint analysis they are subjected to principle component analysis, following the methodology proposed by Giordano (2002). The study is applied to a sample of franchisors which operate in the travel agency industry in Spain.

This article differs substantively from the earlier study in three aspects. First, it analyzes the characteristics of the franchisee profile using a methodology not used within this sector, such as conjoint analysis. Second, it combines conjoint analysis results with principal component analysis. Third, in order to avoid the potential variability that may arise from the use of data from several industries, this study only uses data from travel agency industry.

The structure of the work is as follows. A review of the existing literature on franchisee profile characteristics is made in the next section. The methodology of conjoint analysis and how its results can be combined with principle component analysis is described in section 3. The empirical study made on franchisors in Spain is detailed in section 4. The obtained results are described in section 5 and, finally, the results are discussed and the most interesting conclusions are described in the last two sections. 


\section{Franchisee Profile Characteristics}

The longevity and success of franchising may be due to the fact that, organizationally, it represents a collaborative alliance (Hoffman \& Preble, 2003) that depends on the cooperation of two entrepreneurs (franchisor/franchisee) in order to be successful (Shane \& Hoy, 1996).

The selection of franchisees is perceived as an important problem for the franchisors. An appropriate selection of franchisees can produce remarkable results, whereas a poor selection can cause problems within the franchise system (Justis \& Judd, 1989). These problems are fundamentally derived from the conflicts that can arise between the franchisor and the franchisee, which cause different agency costs, as the agency theory describes.

In all probability, the future success of franchisors depends on a systematic screening process used to ensure careful selection of good prospects to conduct the business of the franchisor (Olm, Eddy, \& Adaniya, 1988; Poe, 1991). A good franchisee, selection system is a key point in differentiating successful franchisors from the rest (Carroll \& Bassuk, 2002).

Selection of franchisees depends on the early and mature stages of franchising (Frazer \& Winzar, 2005). Many franchisors admit to choosing unsuitable franchisees in their early days, sometimes out of a need to quickly start up the system and at other times due to incorrect selection criteria.

Jambulingam and Nevin (1999) comments that an efficient contract between a franchisor and a franchisee could be established by the use of selection criteria which would screen prospective franchisees, based on their likely future outcomes which are desired by their franchisors. The results of this study show that certain attitudes of the franchisees toward the business can be used by the franchisors in the selection process, as the results achieved by the franchisees depend to a great extent on those attitudes. The franchisees with suitable characteristics that are selected can reduce agency costs for the franchisor as less monitoring or control costs would exist.

The franchise system of distribution may better suit the needs of some prospective franchisees than others (Jambulingam \& Nevin, 1999). Some franchisees enter the franchise system and make a great- er contribution to the success of their brand than others who, on the contrary, fail in their work.

A franchisor must recruit people who are not only qualified financially, but who also have ability, energy, and enthusiasm to form the right relationships (Clarkin \& Swavely, 2006). In this context, many franchisors will select franchisees who have no previous experience in the industry (McCosker \& Frazer, 1998; Mendelsohn, 1993), and some even actively recruit inexperienced franchisees because they feel they will be easier to indoctrinate into the system (Frazer, 2001). Cho (2004) recommends that franchising companies should select potential franchisees who have appropriate entrepreneurial personality traits.

The European Code of Ethics for Franchising emphasizes the importance of the franchisee selection, and proposes that a franchisor should select and accept only those franchisees who, upon reasonable investigation, appear to possess the basic skills, education, personal qualities, and financial resources sufficient to carry on the franchised business. This demonstrates the importance of looking for an appropriate franchisee profile.

Bordonaba (2003) studied the reasons why a franchisor would not renew a contract with some of the franchisees in Spain. The study found that $12.8 \%$ of the franchisors would not renew the contract of some of their franchisees because the franchisee profile was not suitable. This provides an idea of the importance to the franchisor of defining and finding a suitable franchisee profile.

A summary of the main works on franchisee profile characteristics which have been analyzed can be seen in Table 1.

In spite of the studies analyzed, there is apparently little consensus between franchisors about the ideal franchisee (DeCeglie, 1993). Many franchisors prefer candidates experienced in businesses or management; however, others do not give much importance to this aspect. Many franchisors will select franchisees who have no previous experience in the industry (McCosker \& Frazer, 1998; Mendelsohn, 1993) and some even actively recruit inexperienced franchisees because they feel they will be easier to indoctrinate into the system (Frazer, 2001).

Similarly, Clarkin and Swavely (2006) comment that little is known about how franchisors evaluate the personal characteristics of franchisees. In their 
Table 1

Main Research on the Franchisee Profile

\begin{tabular}{ll}
\hline Authors & Primary Objective
\end{tabular}

Tatham, Douglas, and Bush (1972)

Edens, Self, and Grider (1976)

Knight (1986)

Withane (1991)

Castrogiovanni, Justis, and Julian (1993)

DeCeglie (1993)

Forward and Fulop (1993)

Kahn (1994)

Hing (1995)

Kaufmann and Stanworth (1995)

Shubart and Bennett (1997)

Falbe and Welsh (1998)

Fenwick and Strombon (1998)

Jambulingam and Nevin (1999)

Berni (2002)

Kasselmann, De Beer, and Vermeulen (2002)

Cho (2004)

Clarkin and Swavely (2006)

Ramirez (2007)
Specify several criteria used in the profile by order of importance.

Determine what biographical, past, and personality characteristics are more important.

Detect which are the personal characteristics of the franchisees required to achieve success.

Determine what personal and entrepreneurial characteristics of the franchisees are necessary for the success of the franchise.

Identify the characteristics of the more qualified franchisees.

Identify the ideal franchisee profile.

Determine what characteristics franchisors consider as more important in franchisees.

Identify the ideal franchisee profile.

Determine what franchisee characteristics can contribute to their satisfaction.

Determine various characteristics in potential franchisees who are interested in becoming franchisees.

Determine the average franchisee profile by means of a descriptive study.

Perceptions of the franchisees about the characteristics associated with the success and failure of franchisees.

Verify if various characteristics in the past of the franchisees are determinants for the operation of the franchise.

Relate the criteria used in the selection of franchisees to the results desired by the franchisors.

Determine the basic values that are common to all successful franchisees.

Identify the personality characteristics of successful franchisees in the fast food industry.

Factors of potential franchisees that contribute to the development of the franchised hotels market

Measure the importance of six criteria used in the franchisee selection process.

Preferences of the franchisors on the franchisee profile

Source: own elaboration.

opinion, the comparative importance that franchisors assign to various franchisee selection criteria has thus far not been systematically examined.

Therefore, the study of both the personal and entrepreneurial characteristics of the franchisee is of vital importance for the success of the franchisorfranchisee relationship and, consequently, for the development of the franchise system.

\section{Theoretical Framework}

Conjoint analysis is a methodology in which a decision maker has to choose from a number of op- tions that vary simultaneously from between two or more attributes (Green, Krieger, \& Wind, 2001). Researchers describe products or services by sets of attribute values or levels and then measure respondents' purchase interest (McCullough, 2002). It presents respondents or judges with several hypothetical products or services, each consisting of a combination or stimuli of specified features or characteristics (Myers \& Mullet, 2003). Such stimuli are therefore described by several attributes. The conjoint results go beyond attribute importance and provide quantitative measures of the relative appeal of specific attribute levels (Wyner, 1992). 
In this article the methodology of Giordano (2002) is followed. The conjoint analysis model can be rewritten as the following multivariate regression model $Y=X B+E$ (1), where the dependent variable $Y$ is an $N \times J$ matrix of judgments expressed as rating on a set of $N$ stimuli, $X$ is the $N \times(K-p)$ full rank design matrix, $B$ is the $(K-$ $p) \times J$ matrix of individual part-worth coefficients, and $E$ is the $N \times J$ matrix of error terms. $X$ is the matrix of explanatory variables that can be written as binary indicator vectors associated with the levels of each attribute. A fractional factorial design is often used in conjoint analysis to represent the complete design based on a smaller number of stimuli (Addelman, 1962; Green \& Srinivasan, 1978). The matrix $X$ must be accordingly coded and shaped. It can be considered that matrix $X$ is a portioned matrix consisting of $p$ juxtaposed indicator matrices $X_{h}(h=1, \ldots, p)$ of general element $x_{i k} \epsilon$ $\{0,1\},(I=1, \ldots, Q)$.

$$
X=\left[X_{1}\left|X_{2}\right| \cdots\left|X_{h}\right| \cdots \mid X_{p}\right]
$$

The model explains how important each attribute is in the stated overall preference (Giordano, 2002). The relative importance of each attribute can be calculated by the sum of the utility ranges for all attributes, and multiplying by 100 . The individual part-worth coefficient estimates $\hat{B}=\left(X^{\prime} X\right)-1 X^{\prime} Y$ (2) can be obtained by minimizing the expression $\min _{B}\|Y-X B\|^{2}$.

In order to improve the interpretation of the conjoint analysis results, the methodology proposed by Giordano (2002) called Principal Component Analysis on a Reference Subspace (PCAR) was used. This technique allows the multivariate response variables to be summarized by performing a Principal Component Analysis. The PCAR geometrical interpretation allows even more enrichment of the Conjoint Analysis by joint plots of attribute levels, judges, and stimuli. Principal Component Analysis can be applied to the matrix $\hat{Y}$ following the equation $\hat{Y}^{\prime} \hat{Y} u_{\alpha}=\lambda_{\alpha} u_{\alpha}$ (3), with $u_{\alpha}^{\prime} u_{\alpha}=1$ and $u_{\alpha}^{\prime} u_{\alpha}=0$ $\forall \alpha \neq \alpha$.

According to (1) and (2), it can be written as $\hat{Y}=$ $X \hat{B}=X\left(X^{\prime} X\right)^{-1} X Y(4)$, which leads to $\hat{Y}^{\prime} \hat{Y}=\hat{Y}^{\prime} X$ $\left(X^{\prime} X\right)^{-1} X^{\prime} X\left(X^{\prime} X\right)^{-1} X^{\prime} Y(5)$.

The expression (3) can be written as $Y^{\prime} X\left(X^{\prime} X\right)^{-1}$ $X^{\prime} Y u_{\alpha}=\lambda_{\alpha} u \alpha(6)$.
Following the approach proposed by Giordano (2002), the $\lambda_{\alpha}$ are the eigenvalues corresponding to the nonzero positive values of (6), arranged in nonincreasing order. The eigenvectors $u_{\alpha}$ are the weights for the $J$ respondents in the aggregated preference model $\overline{\hat{Y}}_{\alpha}=X\left(X^{\prime} X\right)^{-1} X^{\prime} Y u_{\alpha}=X B u_{\alpha}(7)$, where $\alpha=1$, $\ldots,(K-p)$ defines the axes in the geometrical representation.

The coordinates of the $N$ stimuli are computed as the formula (7).

The factorial approach to conjoint analysis by the Giordano (2002) methodology allows the relationships between the judges, the attribute levels, and the stimuli to be represented on a two dimensional space.

The coordinates of the attribute levels are Coor $\left(X_{k}\right)=\left(X^{\prime} X\right)^{-1 / 2} X^{\prime} Y u_{\alpha}$. In the same sense, the coordinates of the $J$ respondents are $\operatorname{Coor}\left(Y_{j}\right)=\sqrt{\lambda_{\alpha}} u_{\alpha}$.

In the next section an application is made using the previous methodology in the travel agency industry that operates under franchise.

\section{Franchisors' Preferences in the Travel Agencies Industry}

An application of conjoint analysis has been carried out to identify franchisors' preference concerning franchisees. The first stage in applying conjoint analysis is to identify the attributes and levels that are going to make up the desired profile. To obtain the attributes, a survey of experts in franchising has been used, by means of a directed nonrandom sampling method, in order to value the different characteristics that may shape the franchisee profile. These experts were selected from among members of associations of franchising chains, university professors researching franchising, managers of franchising consultants, editors of magazines from this sector, managers of websites focused on franchising, and managers of the area of franchising from financial companies specializing in franchising. In this selection of experts, franchisors were not considered, to avoid the effect that their own experience could cause. A questionnaire with a set of features which can be associated with the franchisee profile was sent to each of these experts. The experts had to mark the seven characteristics they considered most desirable for a franchisee candidate. ${ }^{1}$ The characteristics sent to the experts were 
obtained from existing studies which analyzed the franchisee profile.

The sample size of experts was 73. Data collection was carried out between December 2008 and January 2009, by means of a questionnaire sent by e-mail. The total number of questionnaires received was 39 , which represents a response rate of $53.4 \%$.

The 10 attributes most frequently marked were: managerial capability, capacity for human relations, entrepreneurship, desire for success, willingness to work hard, previous experience in any business, ability to adapt to changes, loyalty to franchisor, financial level, and perseverance. ${ }^{2}$

Once the attributes have been identified, the next step is the establishment of levels. Levels constitute the real measures in the construction of the attributes. Therefore, levels have been defined by searching for similarity to reality and are shown in Table 2. Conjoint Analysis is a multivariate technique with fewer theoretical assumptions than other techniques. Nevertheless, the practical assumptions are higher, as the researcher must specify the design of

Table 2

Identification of Attributes and Establishment of Levels

\begin{tabular}{|c|c|}
\hline Attributes & Levels \\
\hline Managerial capability & $\begin{array}{l}\text { Senior manager } \\
\text { Junior manager } \\
\text { No managerial capability }\end{array}$ \\
\hline Capacity for human relations & $\begin{array}{l}\text { Extrovert } \\
\text { Introvert }\end{array}$ \\
\hline Entrepreneurship & $\begin{array}{l}\text { Entrepreneur } \\
\text { Non-entrepreneur }\end{array}$ \\
\hline Desire for success & $\begin{array}{l}\text { High desire for success } \\
\text { Low desire for success }\end{array}$ \\
\hline Willingness to work hard & $\begin{array}{l}\text { Full-time } \\
\text { Part-time } \\
\text { Other people work }\end{array}$ \\
\hline $\begin{array}{l}\text { Previous experience in any } \\
\text { business }\end{array}$ & $\begin{array}{l}\text { Previous experience } \\
\text { No previous experience }\end{array}$ \\
\hline Loyalty to franchisor & $\begin{array}{l}\text { Very loyal } \\
\text { Loyal to some extent } \\
\text { Not loyal }\end{array}$ \\
\hline Financial level & $\begin{array}{l}\text { Above required investment } \\
\text { Only required investment }\end{array}$ \\
\hline Perseverance & $\begin{array}{l}\text { With perseverance } \\
\text { Without perseverance }\end{array}$ \\
\hline
\end{tabular}

the model, its estimation, and its interpretation (Hair, Anderson, Tatham, \& Black, 1999).

A total of 18 cards or combinations established in the orthogonal design were shown to the respondents. Each person interviewed had to score on a scale of 1 (least favorite) to 7 (most favorite). Therefore, a metric scale was used, because this is the one which provides the most reliable results among the different scale possibilities of the dependent variable (Ramirez \& Rondan, 2004).

The questionnaire was sent by e-mail and post, between April and June 2009, to the 20 franchisors that operate in the travel agency industry in Spain. There were 8 valid answers obtained, representing a response rate of $40 \% .^{3}$ The results obtained formed part of a wider study carried out with all the franchisors which operated in Spain.

\section{Results}

Statistical Package for the Social Science (SPSS) Categories module was used in order to apply conjoint analysis. SPSS offers information on the relative importance of attributes and partial utility of levels (Table 3).

It can be seen that the most important attributes that the franchisee must have, according to the opinion of the franchisors that operate in the travel agency industry, are management capacity (22.53\%), the capacity for hard work (16.52\%), and loyalty to the franchisor $(16.36 \%)$. The least important attributes are: previous experience in any business (3.89\%) and an entrepreneurial character $(6.75 \%)$. The importance given to the rest of the attributes is in between the values indicated above.

Other information that SPSS offers is the partial utility. The partial utility can be interpreted as the satisfaction that the respondent group reports for each one of the levels.

Therefore, the franchisee profile preferred by the franchisors who operate in the travel agency industry is determined by those levels that present the higher partial utility within each attribute. As a consequence, the franchisee profile would have to be a candidate with managerial capabilities at a professional level, be extrovert, have an entrepreneurial character, a very accentuated desire for success, working full-time in the franchisee unit, having had previous experience in any business which faith- 
Table 3

Relative Importance of Attributes and Partial Utility of the Levels Associated With the Franchisee Profile

\begin{tabular}{|c|c|c|c|}
\hline Attributes & $\begin{array}{l}\text { Average } \\
\text { importance }\end{array}$ & Levels & Utility \\
\hline Managerial capability & 22.533 & $\begin{array}{l}\text { Senior manager } \\
\text { Junior manager } \\
\text { No managerial capability }\end{array}$ & $\begin{array}{r}0.719 \\
0.016 \\
-0.734\end{array}$ \\
\hline Capacity for human relations & 7.824 & $\begin{array}{l}\text { Extrovert } \\
\text { Introvert }\end{array}$ & $\begin{array}{r}0.195 \\
-0.195\end{array}$ \\
\hline Entrepreneurship & 6.753 & $\begin{array}{l}\text { Entrepreneur } \\
\text { Non-entrepreneur }\end{array}$ & $\begin{array}{r}0.195 \\
-0.195\end{array}$ \\
\hline Desire for success & 7.475 & $\begin{array}{l}\text { High desire for success } \\
\text { Low desire for success }\end{array}$ & $\begin{array}{r}0.227 \\
-0.227\end{array}$ \\
\hline Willingness to work hard & 16.524 & $\begin{array}{l}\text { Full-time } \\
\text { Part-time } \\
\text { Other people work. }\end{array}$ & $\begin{array}{r}0.427 \\
-0.401 \\
-0.026\end{array}$ \\
\hline Previous experience in any business & 3.887 & $\begin{array}{l}\text { Previous experience } \\
\text { No previous experience }\end{array}$ & $\begin{array}{r}0.039 \\
-0.039\end{array}$ \\
\hline Loyalty to franchisor & 16.359 & $\begin{array}{l}\text { Very loyal } \\
\text { Loyal to some extent } \\
\text { Not loyal }\end{array}$ & $\begin{array}{r}0.469 \\
0.016 \\
-0.484\end{array}$ \\
\hline Financial level & 9.297 & $\begin{array}{l}\text { Above required investment } \\
\text { Only required investment }\end{array}$ & $\begin{array}{r}0.133 \\
-0.133\end{array}$ \\
\hline Perseverance & 9.348 & $\begin{array}{l}\text { With perseverance } \\
\text { Without perseverance }\end{array}$ & $\begin{array}{r}0.258 \\
-0.258\end{array}$ \\
\hline
\end{tabular}

Constant: 3.229. Pearson rho coefficient: 0.973, significance: 0.0000 ; Kendall tau coefficient: 0.811 ; significance: 0.0000 .

fully follows the requirements of the franchisor. The franchisee would have a financial level above the required initial investment and have perseverance.

The total utility of any profile or stimulus can be calculated by adding the higher partial utilities plus the constant. In the case of the previously described profile, its total utility will be worth:

$$
\begin{aligned}
\mu_{i}= & 0.719+0.195+0.195+0.227+0.427+0.039 \\
& +0.469+0.133+0.258+3.229=5.891
\end{aligned}
$$

In this way the total utility of any profile or stimulus can be calculated, and will always give a value less than 5.891. This can also be used to analyze and compare which profiles are preferred by the franchisors who operate in the travel agency industry.

Values close to the Spearman rho and Kendall tau coefficients indicate that the results obtained are trustworthy.
The results obtained with the conjoint analysis are deduced from the opinion of the global set of all the respondents. However, when the opinions of the respondents are not homogenous, patterns of preferences can arise that are different from the preference obtained for the total of the set. In this sense, with the objective of improving the interpretation of the results provided by the conjoint analysis, the methodology proposed by Giordano (2002) was applied to the data that were obtained in the survey.

Table 4 shows the obtained eigenvalues. The first eigenvalue gives $96.23 \%$ of the total variability, whereas the first two eigenvalues give $97.62 \%$. Therefore, the first two eigenvalues are sufficient as they express a very high percentage of total variability.

Table 5 shows the coordinates of the levels in the two main axes, and the importance of each attribute in each one of the two main axes. 
Table 4

Eigenvalues and Their Total Contribution

\begin{tabular}{rrr}
\hline Eigenvalue & Percent & Cumulated \\
\hline 1845.53 & 96.23 & 96.23 \\
26.77 & 1.40 & 97.62 \\
15.56 & 0.81 & 98.44 \\
14.22 & 0.74 & 99.18 \\
7.87 & 0.41 & 99.59 \\
5.53 & 0.29 & 99.88 \\
2.24 & 0.12 & 99.99 \\
0.14 & 0.01 & 100.00 \\
\hline
\end{tabular}

On each axis, the relative importance of an attribute can be calculated by dividing the range of coordinates for each attribute by the sum of level coordinate ranges for all attributes. Thus, an attribute will be more important when it has a greater difference between the highest and the lowest range.

Each factorial axis is a synthesis of the preference variables (Giordano, 2002). Each axis describes the preference of a homogeneous subset of respondents toward the attribute levels. Giordano (2002) shows that the first factorial axis determines the maximum agreement system within judges, while the successive ones establish alternative preference patterns of judges' subsets.

The representation of the attribute levels allows expression of the preferences of the total set of respondents. The preference of the individuals is determined by those levels that are closer to the coordinates of the individuals.

Equally, the individuals who show the same

Table 5

Coordinates of Levels and Attributes Importance

\begin{tabular}{|c|c|c|c|c|}
\hline Attributes/Levels & Axis 1 & Axis 2 & $\begin{array}{c}\text { Important } \\
\text { Attribute } \\
\text { Axis } 1\end{array}$ & $\begin{array}{c}\text { Important } \\
\text { Attribute } \\
\text { Axis } 2\end{array}$ \\
\hline Managerial capability & & & $8.04 \%$ & $39.16 \%$ \\
\hline Senior manager & 19.01 & 16.60 & & \\
\hline Junior manager & 0.23 & 8.01 & & \\
\hline No managerial capability & -19.24 & -24.61 & & \\
\hline Capacity for human relations & & & $3.75 \%$ & $3.65 \%$ \\
\hline Extrovert & 8.93 & -1.92 & & \\
\hline Introvert & -8.93 & 1.92 & & \\
\hline Entrepreneurship & & & $3.53 \%$ & $8.70 \%$ \\
\hline Entrepreneur & 8.39 & 4.58 & & \\
\hline Non-entrepreneur & -8.39 & -4.58 & & \\
\hline Desire for success & & & $10.02 \%$ & $3.95 \%$ \\
\hline High desire for success & 23.84 & 2.08 & & \\
\hline Low desire for success & -23.84 & -2.08 & & \\
\hline Willingness to work hard & & & $5.49 \%$ & $19.81 \%$ \\
\hline Full-time & 14.82 & -3.47 & & \\
\hline Part-time & -3.52 & -8.69 & & \\
\hline Other people work & -11.30 & 12.16 & & \\
\hline Previous experience in any business & & & $10.24 \%$ & $1.10 \%$ \\
\hline Previous experience & 24.37 & 0.58 & & \\
\hline No previous experience & -24.37 & -0.58 & & \\
\hline Loyalty to franchisor & & & $13.20 \%$ & $8.42 \%$ \\
\hline Very loyal & 27.50 & -1.72 & & \\
\hline Loyal to some extent & 7.81 & 5.29 & & \\
\hline Not loyal & -35.31 & -3.57 & & \\
\hline Financial level & & & $28.30 \%$ & $2.34 \%$ \\
\hline Above required investment & 67.33 & -1.23 & & \\
\hline Only required investment & -67.33 & 1.23 & & \\
\hline Perseverance & & & $17.42 \%$ & $12.87 \%$ \\
\hline With perseverance & 41.43 & -6.77 & & \\
\hline Without perseverance & -41.43 & 6.77 & & \\
\hline
\end{tabular}


preferences are represented by vectors in the same direction, in such a way that they may constitute market segments.

Also, the position of the stimuli in the graph allows the stimulus preferred by the respondents to be obtained. The nearer they are to both coordinates, the greater the preference.

It is very important to show that when the whole group of respondents is homogeneous in their preferences, the first factorial axis is very close to the results of traditional conjoint analysis.

Figure 1 shows the joint representation of the attribute levels, stimuli, and individuals.

The first axis represents the required level of investment, perseverance, and loyalty to the franchisor in opposed points. According to the distance which separates the different attribute levels from this axis, the most important attribute is the financial level, followed by that of perseverance, and later by loyalty to the franchisor. These data corroborate the importance obtained in Table 5. The explanatory power of this axis is $96.23 \%$, as is shown in Table 4 .

The second axis is clearly expressed for managerial capacity. Nevertheless, this second axis has a very low explanatory power $(1.40 \%)$, which is why it must be interpreted as the existence of some pattern different from the total; that is to say, the existence of some subgroups of respondents who value managerial capacity as more important.

Another important aspect is that the graphical representation of the respondents shows the existence of two differentiated groups with similar preferences. A group is formed by judges 1, 4, 8, and 5 , whereas the other group is formed by judges $2,3,6$, and 7 . Therefore, these two groups constitute good market segmentation.

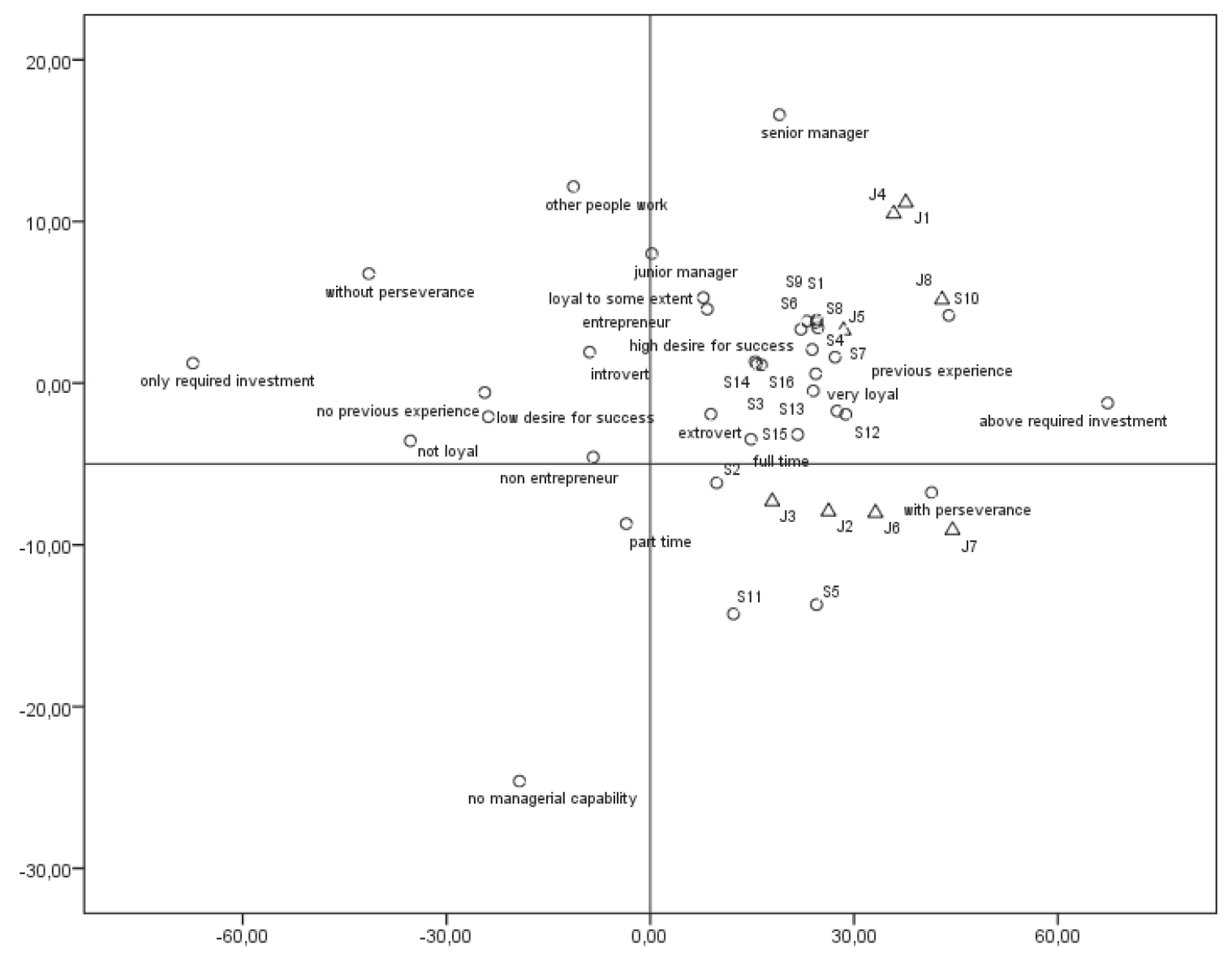

Figure 1. Representation of attribute levels, stimuli, and franchisors. 
Finally it is necessary to comment that the first group above considers 10 the most favorite stimulus, whereas the second group considers 5 the most favorite stimulus.

\section{Discussion and Managerial Implications}

The purpose of this article was to analyze the preferences of franchisors in travel agency industry. Specifically the study tried to identify the franchisee profile preferred by franchisors in this industry.

One way of obtaining this profile is by applying the methodology of conjoint analysis. With this methodology the characteristics that form the franchisee profile can be obtained, as well as a ranking of the most important attributes that must be present in this profile. Nevertheless, the interpretation of the results obtained in the conjoint analysis can be improved by means of the application of a principal component analysis, following the methodology proposed by Giordano (2002).

Conjoint analysis showed that of all the analyzed attributes, the most important was managerial capacity, with a relative importance of $22.53 \%$. This was followed by the capacity for hard work $(16.52 \%)$ and loyalty to the franchisor (16.36\%). The less important attributes were previous experience in any business $(3.89 \%)$ and the entrepreneurial character $(6.75 \%)$. The importance given to the rest of the attributes lay between the previously indicated values.

Therefore, a franchisee who operates within a brand of the travel agency industry will have to be a person who fundamentally has knowledge and command of the management tools necessary for the development of the business. It is also important that they have the capacity to work hard, that is to say, have a strong spirit, desire to work and to assume responsibilities, and to be able to confront the daily task of the business referring to its organization and management. They must also be a person who shows loyalty to the franchisor. Loyalty is understood as the fulfillment of the agreements established between the parties. On the other hand, having previous experience in any business is not given much value. Sometimes previous experience in any business is seen as an obstacle because the franchisees must change or modify the habits acquired during many years of professional activity (Díez, Navarrro, \& Rondán, 2005).

Other information that was obtained was the par- tial utility of the levels; that is to say, the satisfaction reported for each of the levels by the respondents.

Therefore, the franchisee profile preferred by the franchisors that operate in the travel agency industry will be determined by those levels that present the higher partial utility within each attribute. As a consequence, the franchisee profile would have to be a candidate with managerial capabilities at a professional level, be extrovert, have an entrepreneurial character, a very accentuated desire for success, working full-time in the franchisee unit having had previous experience in any business, who faithfully follows the requirements of the franchisor. The franchisee would have a financial level above the required initial investment and have perseverance.

All these results were obtained when applying the conjoint analysis, however, the interpretation of these results must be made carefully because individual preferences can be analyzed jointly and it could be that those individuals have very different opinions. In this case preference patterns can arise that are different from those obtained for the total set of respondents. With the objective of improving the interpretation of these results, a principal component analysis was applied following the methodology proposed by Giordano (2002). The first axis represents the opinion of the total set of the respondents. Through this methodology it was discovered that the most important attribute was the financial level of the potential franchisee, followed by their perseverance and loyalty to the franchisor.

Therefore, in the travel agency industry the franchisors fundamentally value a person who has a high financial level, in order to not only confront the start of the economic activity, but to take the business to the point of stability at which it begins to generate profits. This result is in agreement with that found by Tatham et al. (1972) whereby the financial level was the most important attribute at the time of selecting a franchisee. The importance of having economic resources can also be appreciated at the time of renewing the franchisees. Bordonaba (2003) showed that the lack of payment of quotas or fees is one of the reasons for which the franchisor would not renew franchisees. At the general franchising level, the consideration of the financial level as one of the most important attributes that the franchisors look for in the potential franchisees is 
also corroborated by the studies of DeCeglie (1993), Edens et al. (1976), Hing (1995), Knight (1986), Ramirez (2007), and Tormo (2004).

Also franchisors seek out people who have perseverance. Some people erroneously see franchising as an infallible system, from which they expect profits from the very beginning. Franchising, as with the start up of any business activity, requires time and motivation, which is why perseverance is sought as an important element at the time of looking for potential franchisees for the travel agency industry.

It is also very important in the travel agency industry that the franchisee has loyalty to the franchisor. Loyalty is understood as the fulfillment of the agreements established between the parties. Franchising is a system in which the capacity of the franchisee to make their own business decisions is limited to a great extent, and any innovation, modification, or peculiarity that they consider applying are rejected in this associative system. Faced with this reality, a potential franchisee must consider whether their personality is appropriate to accept such limitations of their own autonomy. This does not mean that the franchisee is a person devoid of initiative and personality, but that any initiative must be raised and follow the channels established by the franchisor and not be implemented independently (Díez et al., 2005).

There are some attributes that are less important at the time of selecting a potential franchisee for the travel agency industry. One of them is the entrepreneurial character. Within the franchise system it is necessary to differentiate between those people who introduce themselves into the system looking for a self-employed formula and those who look for an activity in which to invest. The first case refers to a person with an entrepreneurial character, who is going to develop a business activity, and must confront and solve all its inherent problems. The second case refers to an investor who does not need to attend to his business on a day to day basis. In the travel agency industry it is not important to make this distinction, which is why it is a characteristic that is not given very much consideration at the time of selecting the future franchisee. The degree of extroversion or introversion of the franchisee is also little valued. The financial level, perseverance, and loyalty to the franchisor are much more important than being extrovert or introvert.
In summary, the ranking of attributes preferred by the franchisors of the travel agency industry is 1) financial level; 2) perseverance; 3) loyalty to franchisor; 4) previous experience in any business; 5) desire for success; 6) managerial capability; 7) willingness to work hard; 8) capacity for human relations; and 9) entrepreneurship.

The second factorial axis has a very low explanatory value in relation to the first, as it only explains $1.40 \%$ of the total variability. Therefore, it is possible to be interpreted as a pattern of preferences different from that obtained with the first factorial axis. In fact, in Graph 1, two differentiated groups of franchisors are distinguishable, which indicates that two groups exist with different preferences. This second axis is clearly determined for managerial capacity. It indicates that there is a subgroup of franchisors in the travel agency industry which considers that managerial capacity is a very important attribute at the time of selecting a potential franchisee.

Managerial capacity refers to the knowledge and command of the management tools necessary for the development of the business. What seems clear is that the managerial capacity will be different in some travel agencies to that in others, since they will be related to the level of turnover and the business structure of the points of sale.

The differences existing between the results obtained with the conjoint analysis and those obtained with the principal component analysis must be due to the existence of two groups of franchisors that display different preferences. The greater the homogeneity of the preferences of the respondents, the greater will be the consistency between the results obtained in both methodologies.

\section{Conclusions}

In this work the franchisee profile preferred by the franchisors who operate in the travel agency industry has been examined. This has been achieved by applying the methodology of conjoint analysis and the methodology of principal component analysis (Giordano, 2002) to a sample of Spanish franchisors. As a conclusion, it can be said that the main characteristics that the franchisors of the travel agency industry consider, at the time of selecting potential franchisees, are the financial level, perseverance and loyalty to the franchisor. Other charac- 
teristics exist that, in spite of having been analyzed in the literature, are not so important at the time of selecting a potential franchisee. The analysis of levels also allows the deduction of ideal franchisee profile in travel agency industry, although the generalization of the results must be made carefully.

In relation to the practical and theoretical contributions, this paper contributes to franchisee selection criteria of franchise literature. Also it contributes to the limited literature about franchising and travel agency industry. Practitioners and academics could obtain benefits from this research because they can identify the franchisee profile franchisors prefer in the service industry. In particular, these criteria help to practitioners to make the right selection of franchisees.

It is important to indicate that the small divergences existing between the results obtained by the conjoint analysis and those obtained by the principal component analysis must be fundamentally due to the heterogeneity of the preferences of the respondent franchisors. The principal component analysis allowed the discovery of two subgroups of franchisors with different preference structures, which is why a high homogeneity in the preferences of all the respondent franchisors does not exist.

In this study it had been important to interview all the franchisors who operate within the travel agency industry, but sometimes it is difficult to obtain a greater number of responses. Also, there are travel agency industries with different characteristics and situations in many countries. For example, in the US, travel agencies are on the decline and airlines are no longer paying travel commissions to travel agencies, which today serve primarily the cruise industry and international air travel. Therefore, the conclusions of this study must be considered carefully in order to generalize the results to other markets.

In the future, it would be interesting to apply this study to other sectors and to compare the results to see if sectoral differences exist or not. It would also be interesting to apply this same study in different countries to determine if the geographical situation influences the franchisee profile preferred by the franchisors.

\section{Acknowledgment}

The authors wish to acknowledge to the two reviewers for their relevant comments that have contributed to significantly improve the article.

\section{Notes}

${ }^{1}$ Only nine attributes were considered because a greater number can produce a set of stimuli too high to be evaluated by respondents.

${ }^{2}$ From these 10 attributes the capacity for adaptation to changes has been considered as a variable depending to a greater extent on franchisors than franchisees, because franchisors are the ones who have to face and adapt to the evolution of markets through the right strategies and policies. Therefore, this variable has been eliminated from the analysis.

${ }^{3}$ In spite there is a minimum sample size, it represents a response rate of $40 \%$. In order to avoid variability in the results this study uses data from only travel agency industry. This justifies the use of a low sample size, but it implies a high response rate. Response rates for e-mail surveys can range from $6 \%$ to $75 \%$ (Sheehan \& McMillan, 1999). Another study conducted by Cook, Heath, and Thompson (2000) reported an average of about $40 \%$ for response rates from a synthesis of 39 separate online surveys. More information can be found in Pan's study (2010).

\section{References}

Addelman, S. (1962). Orthogonal main-effect plans for asymmetrical factorial experiments. Technometrics, 4(1), 21-46.

Berni, F. (2002). Corel values: Keys to finding successful franchisees. Franchising World, 34(4), 15-17.

Bordonaba, M. V. (2003). Determinantes del éxito de las relaciones comerciales a largo plazo entre empresas: Análisis empírico en el sistema de franquicia. Doctoral thesis (in Spanish), Department of Business Administration, Zaragoza University, Spain.

Carroll, C., \& Bassuk, H. (2002). The characteristics of great franchise leaders. Franchising World, 34(1), 10-11.

Castrogiovanni, G. J., Justis, R. T., \& Julian, S. D. (1993). Franchise failure rates: An assessment of magnitude and influencing factors. Journal of Small Business Management, 31(2), 105-114

Cho, M. (2004). Factors contributing to middle market hotel franchising in Korea: The franchisee perspective. Tourism Management, 25(5), 547-557.

Clarkin, J. E., \& Swavely, S. M. (2006). The importance of personal characteristics in franchisee selection. Journal of Retailing and Consumer Services, 13(2), 133-142.

Cook, C., Heath, F., \& Thompson, R. L. (2000). A metaanalysis of response rates in Web- or Internet-based surveys. Educational and Psychological Measurement, 60(6), $821-836$.

DeCeglie, P. (1993). What franchisors look for. Nation's Business, 81(7), 67-81.

Díez, E. C., Navarro, A., \& Rondán, F. J. (2005). El sistema de franquicia. Fundamentos teóricos y prácticos (in Spanish). Madrid: Pirámide.

Dolnicar, S., \& Laesser, C. (2007). Travel agency marketing strategy: Insights from Switzerland. Journal of Travel Research, 46(1), 133-146.

Edens, F. N., Self, D. R., \& Grider, D. T. (1976). Franchisors describe the ideal franchisee. Journal of Small Business Management, 14(3), 39-47. 
Falbe, C. M., \& Welsh, D. H. B. (1998). NAFTA and franchising: A comparison of franchisor perceptions of characteristics associated with franchisee success and failure in Canada, Mexico and the United States. Journal of Business Venturing, 13(2), 151-171.

Fenwick, G. D., \& Strombom, M. (1998). The determinants of franchisee performance: An empirical investigation. International Small Business Journal, 16(4), 28-45.

Forward, J., \& Fulop, C. (1993). Elements of a franchise: The experiences of established firms. The Service Industries Journal, 13(4), 159-178.

Frazer, L. (2001). Causes of disruption to franchise operations. Journal of Business Research, 54(3), 227-234.

Frazer, L., \& Winzar, H. (2005). Exits and expectations: Why disappointed franchisees leave. Journal of Business Research, 58(11), 1534-1542.

Giordano, G. (2002). The non-symmetrical analysis of multi-attribute preference data. In C. Lauro, J. Antoch, V. Esposito Vinzi, \& G. Saporta (Ed.), Multivariate total quality control - foundation and recent advances (pp. 221-236). Heidelberg/New York: Physica-Verlag.

Green, P. E., Krieger, A. M., \& Wind, Y. (2001). Thirty years of conjoint analysis: Reflections and prospects. Interfaces, 31(3), S56-S73.

Green, P. E., \& Srinivasan, V. (1978). Conjoint analysis in consumer research: Issues and outlook. Journal of Consumer Research, 5, 103-123.

Hair, J. F., Anderson, R. E., Tatham, R. L., \& Black, W. C. (1999). Multivariate data analysis. Englewood Cliffs, NJ: Prentice Hall.

Hing, N. (1995). Franchisee satisfaction: Contributors and consequences. Journal of Small Business Management, $33(2), 12-25$.

Hoffman, R. C., \& Preble, J. F. (2003). Convert to compete: Competitive advantage through conversion franchising. Journal of Small Business Management, 41(2), 187-204.

Jambulingam, T., \& Nevin, J. R. (1999). Influence of franchisee criteria on outcomes desired by the franchisor. Journal of Business Venturing, 14(4), 363-395.

Justis, R., \& Judd, R. (1989). Franchising. Cincinnati: South-Western Publishing Company.

Kahn, M. (1994). Franchise et partenariat. Dalloz, Paris, 30-31.

Kandampully, J. (1995). Tourism in the south west: present posibilitéis and future projections. The Journal of Interdisciplinary Economics, 6, 169-181.

Kandampully, J. (2000). The impact of demand fluctuation on the quality of service: A tourism industry example. Managing Service Quality, 10(1), 10-18.

Kasselmann, B., De Beer, J. J., \& Vermeulen, L. P. (2002). Personality attributes of successful franchisees in the fast foods sector in South Africa. South African Journal of Economic and Management Sciences, 5(1), 154-179.

Kaufmann, P. J., \& Stanworth, J. (1995). The decision to purchase a franchise: A study of prospective franchisees. Journal of Small Business Management, 33(4), 22-32.

Knight, R. M. (1986). Franchising from the franchisor and franchisee points of view. Journal of Small Business Management, 24(3), 8-15.
McCosker, C., \& Frazer, L. (1998). Franchising Australia 1998: A survey of franchising practices and performance. Toowoomba: USQ.

McCullough, D. (2002). A user's guide to conjoint analysis. Marketing Research, 14(2), 18-23.

Mendelsohn, M. (1993). The guide to franchising (5th ed.). London: Cassell.

Moreno, S., \& Aguiar, T. (2006). Diagnóstico, tendencias y estrategias de futuro para las agencias de viajes. El caso del sector español. Estudios y Perspectivas en Turismo, $15,327-349$.

Mundofranquicia Consulting. (2008). La franquicia en $\mathrm{Ci}$ fras 2008. Servicio de estudios estadísticos y divulgativos de mundofranquicia consulting. Madrid, Spain.

Myers, J. H., \& Mullet, G. M. (2003). Managerial applications of multivariate analysis in marketing. Chicago, IL: American Marketing Association.

Olm, K. W., Eddy, G. G., \& Adaniya, A. R. (1988). Selecting Franchisee Prospects. Society of Franchising Proceedings II. San Francisco: Society of Franchising.

Pan, B. (2010). Online travel surveys and response patterns. Journal of Travel Research, 49(1), 121-135.

Poe, R. (1991). Self reliance: Sacrifice and persistence lead to franchise success. Success, 38(10), 63-69.

Ramirez, J. M. (2007). Determinación y estudio del perfil de franquiciado mediante la aplicación de análisis conjunto. Doctoral thesis (in Spanish), Department of Economy, Quantitative Methods and Economic History, Pablo de Olavide University, Seville, Spain.

Ramirez, J. M., \& Rondan, F. J. (2004). Evaluación de los procedimientos de medición de la variable respuesta en el análisis conjunto bajo distintas alternativas de estimación (in Spanish). XVIII Reunión Anual ASEPELT, León, Spain.

Shane, S. A., \& Hoy, F. (1996). Franchising: A gateway to cooperative entrepreneurship. Journal of Business Venturing, 11(5), 325-327.

Sheehan, K. B., \& McMillan, S. J. (1999). Response variation in e-mail surveys: An exploration. Journal of Advertising Research, 39(4), 45-54.

Shubart, E., \& Bennett, J. (1997). 75\% franchisees satisfied doing fine. Franchise Times, 3(7), 3-4.

Tatham, R. L., Douglas, R., \& Bush, R. F. (1972). An analysis of decision criteria in franchisor/franchisee selection processes. Journal of Retailing, 48(1), 16-22.

Tormo \& Associates. (2004). Guía de franquicias y oportunidades de negocio 2004. Madrid, Spain.

Withane, S. (1991). Franchising and franchisee behaviour: an examination of opinions, personal characteristics and motives of Canadian franchisee entrepreneurs. Journal of Small Business Management, 29(1), 22-29.

World Tourism Organization. (1998): Introduction to tourism. Madrid: Author.

Wyner, G. A. (1992). Uses and limitations of conjoint analysis-Part I. Marketing Research, 4(2), 42-44.

Xiao, H., \& Smith, S. (2006). The making of tourism research: Insights from a social sciences journal. Annals of Tourism Research, 33, 490-507. 